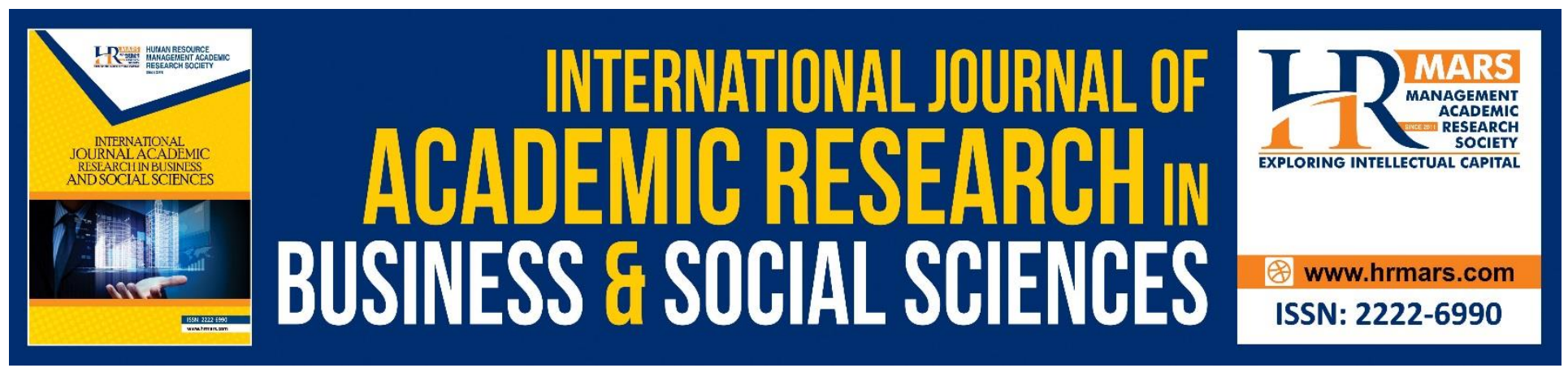

\title{
Forced Migration and Human Trafficking: Religion and Community Perspective in Nigeria
}

Usman Mikail Usman, Nasa'i Muhammad Gwadabe, Sobia Jamil, Mohd
Afandi Salleh, Syed Zohaib Abbas Rizvi

To Link this Article: http://dx.doi.org/10.6007/IJARBSS/v9-i3/5763

DOI: $\quad 10.6007 /$ IJARBSS/v9-i3/5763

Received: 05 Feb 2019, Revised: 23 Feb 2019, Accepted: 04 March 2019

Published Online: 15 March 2019

In-Text Citation: (Usman, Gwadabe, Jamil, Salleh, \& Rizvi, 2019)

To Cite this Article: Usman, U. M., Gwadabe, N. M., Jamil, S., Salleh, M. A., \& Rizvi, S. Z. A. (2019). Forced Migration and Human Trafficking: Religion and Community Perspective in Nigeria. International Journal Academic Research Business and Social Sciences, 9(3), 1071-1079.

\section{Copyright: (C) 2019 The Author(s)}

Published by Human Resource Management Academic Research Society (www.hrmars.com)

This article is published under the Creative Commons Attribution (CC BY 4.0) license. Anyone may reproduce, distribute, translate and create derivative works of this article (for both commercial and non-commercial purposes), subject to full attribution to the original publication and authors. The full terms of this license may be seen

at: http://creativecommons.org/licences/by/4.0/legalcode

Vol. 9, No. 3, 2019, Pg. $1071-1079$ 


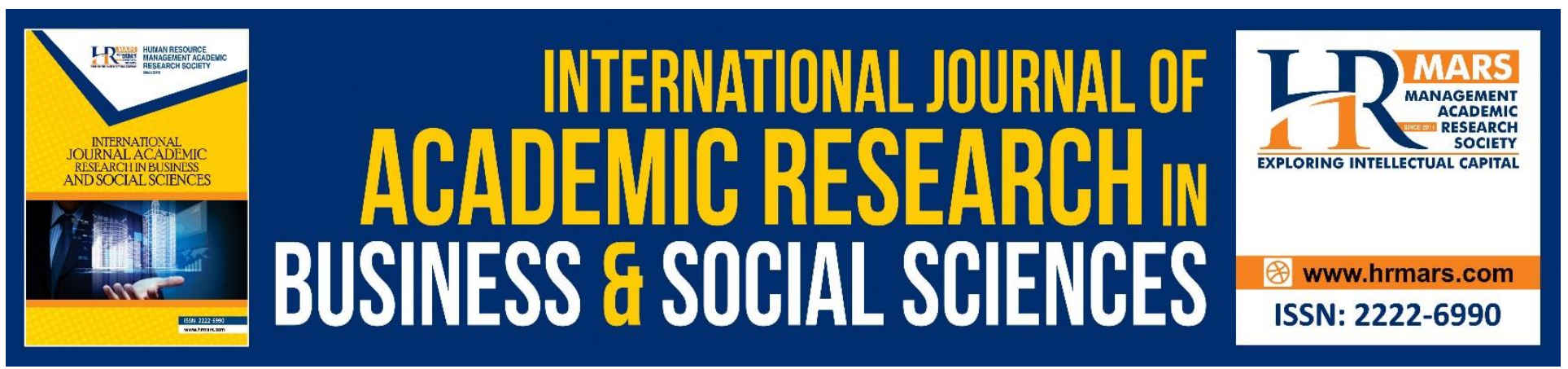

\title{
Forced Migration and Human Trafficking: Religion and Community Perspective in Nigeria
}

\author{
Usman Mikail Usman, Nasa'i Muhammad Gwadabe, Sobia Jamil, \\ Mohd Afandi Salleh, Syed Zohaib Abbas Rizvi
}

Department of Development Studies, University of Malaya, Malaysia. Department of International Relations, Universiti Sultan Zainal Abidin, Malaysia.

Department of Political Science, University of Punjab, Pakistan.

\begin{abstract}
Forced migration and human trafficking are two different but many times interrelated global issues. As a matter of fact, they have become a complicated and never-ending phenomenon. A lot of concerted measures by the governments and relevant stakeholders are in place but far from practical and real results. In fact, in recent past Nigeria has witnessed a significant increase in forced migration and human trafficking more than ever before to overseas countries. Thus, there is nearly no research that links these two critical international issues in Nigeria. Moreover, there is a need for community members and the religious institution as substantial drivers to remedy the plight of migrant and trafficking victims. The study employs a grassroots approach which gives greater emphasis or a particular focus on supporting community development from the bottom-up. This was utilised using process tracing of the qualitative research paradigm. The findings provide the vulnerable victims of forced migration and human trafficking solutions not only in skills acquisition and education but as well as lessen the poverty of the poor individuals in a community. For this reason, significantly contributing to the communities' development and Nigeria as a whole. The other essential part of this study is the vital role the religious institution plays to eradicate forced migration that leads to human trafficking. Interestingly, the suggestion of this article is a practical blueprint for the policy makers to deepen engagements to address this menace and to better the development of communities.
\end{abstract}

Keywords: Forced Migration, Human Trafficking, Community, Religion, Nigeria.

\section{Introduction}

Forced migration and human trafficking are two different but many times interrelated global issues. As a matter of fact, they have become a complicated and never-ending phenomenon. A lot of concerted measures by the governments and relevant stakeholders are in place but far from practical and real results. In fact, in recent past Nigeria has witnessed a significant increase in forced migration 
and human trafficking more than ever before to overseas countries (Usman, 2014). A large number of forced migrants worldwide is from developing countries mainly a result of poverty, ecological, political, civil unrest and government policies. Their situation is presently pursuing a stiff challenge to developed nations governments. Some of these forced migrants ran as a result of threatening disaster or persecution. Forced migration hinders and affects international relations and economic developments of nations (Wood, 1994; Akanle, 2013). Accordingly, Castles \& Miller (2013), sees forced migration as feminization, differentiation, acceleration, and globalization of migration. Thus, the actual number of forced migrants is not known but an estimated figure. Findings by Kunz (cited in Betts, 2009), states that there are two types of forced migrations; anticipatory migration flow which is a small group or an individual tries to escape in anticipating damaging event or situation. Then the acute flow this is when people en masse escape or migrate due to the danger on the ground to the neighboring or other countries.

In general, forced migration usually affect countries history; while international office for Migration (IOM) called it illegal migrants and it is steadily on the rise from just 32milloin in 1987 to 42 million in 1993 to presently 244 million. The majority of the migrants from Africa numbering around 170, 000 arrived in Italy are mostly from Eritrea, Nigeria and Somalia respectively (IOM, 2016). One thing remains certain it mainly happens in countries with a weak standard of living condition. Most likely, the forced migrants are partly from the ethnic conflict zone. However, the international community's remedy proved unresolved to battle the complex and multifaceted forced migration that many times end into human trafficking ring of criminals across transnational borders.

Equally important is that human trafficking is fast becoming widely international crime due to rising forced migration (Usman, Ariffin, \& Othman, 2017). To demonstrate this, the study uses a qualitative inquiry that connects forced migration and human trafficking in Nigeria, due to the limited study on the said subject. In this case, there is the capability and ability of the religious body and communities to curtail the crime. Due to the phenomenal rise of forced migration that makes Nigerian migrants encountered several exploitations, mostly to human trafficking in sexual abuse, labour, and other similar subjugations. Though laws and policies addressing these critical issues exist but do minimal to curtail the scourge. The authors are being motivated that religious body and communities as collective people's voice have a greater and better role to take in hand with the menace of forced migration and human trafficking. This paper is an attempt to fill the literature gap between forced migration and human trafficking as it incorporates religion and communities' perspective. Hence, there is limited scholarly research on the said topic.

\section{Literature Review \\ Forced Migration}

Forced migration is crucial to international relations as it revolves around ethnicity, north-south relations, interdependence, international organizations, international cooperation, non-state actors, regionalism and globalization amongst others. Forced migration is a specialised discipline that cut across anthropology, sociology, geography, and law that tries to end or find a solution to human displacements. Also, forced migration crisscross international borders (Betts, 2009). The 1951 convention of the United Nations High Commission for Refugees (UNHCR, 1951) dealing with migrant refugees call to assist and protect people who escaped oppression or conflict troubled communities. 
Accordingly, Bucker, (2016) said forced migration happens as a result of war as well as institutional, economic and political forces both in the destination and sourced countries are a major concern. According to the author, Germany experienced an unprecedented increase in forced migrants in the year 2016 like never before. This has posed a critical challenge to decision makers, agencies and civil society organisations. Though Bauer, Giesecke, \& Janisch, (2017) is of the opinion that forced migration is linked to higher mortality and migrants are in general in bad situations. This is due to the absence of incorporating forced migrants in communities and lack of joining the market of labour. In the same direction, Erdal, and Oeppen (2018) see migration from two stand points. Either as voluntary or forced migration. The authors cited Afghanistan citizens are viewed as forced migrants and Pakistanis as voluntary migrants. This is in general peoples understanding. But migration is difficult to explain and scholars and populace need to know this. In the words of Reed (2018), forced migration is either the creation of human or of a natural disaster. To Him, it is on the rise and about several millions of such people exist globally. Notably, Reed said they constitute a group of development in many facets to the developed nations such as in skilled work, knowledge transfer, and entrepreneurships. Furthermore, Darling, (2017) combines the city and forced migrants. That is cities are a connection between migrants as refugees and the concept of statist in an international politics of diversity and cultural tensions. The article mentioned cities like Kabul, Nairobi, Johannesburg, Bogota, and Abidjan has witnessed phenomenal developmental wellbeing in the last twenty years as a result of forced migrants in these cities.

In other words, September 11 attacked changed the way migrants from different nationals are handled. They have been subjected to various rigorous untold hardships from detained in camps by the executives exercising their powers, to the evaluation of their nation's activities and to those seen as suspect or threat to national security amongst other things (Karyotis, 2007). Mostly faced different forms and types of abuses. Thus, communities need to stand up its own, in this 21 st century by looking inward to do all it takes within their powers to the forced migrants as Nigerian citizens. The traditional way Nigeria previously known for should be revived and restored that is in terms of neighbor to neighbor assistance and kind relations (Willis, 2011). That is another vital option or way to end forced migrants in the hands of criminal networks that largely put them into more trouble. Truly, the problem of forced migration and human trafficking victims can hardly escape due to traumatic experiences of exploitation abuses. Thus the next section digs into human trafficking as a result of forced migration.

\section{Human Trafficking}

The present global threat pursed by transnational criminal network vis-à-vis trafficking in human calls for international action. While forced migrants run to find basic necessities of life, human traffickers turn victims as a lucrative trade and means to earn money. Migrants are being sold, abused and exploited by all means for a different purpose. To fight the menace more than 160 countries came together signed and ratified the United Nations protocol dealing with human trafficking and defined it as "Trafficking in persons shall mean the recruitment, transportation, transfer, harboring or receipt of persons, by means of the threat or use of force or other forms of coercion, of abduction, of fraud, of deception, of the abuse of power or of a position of vulnerability or of the giving or receiving of payments or benefits to achieve the consent of a person having control over another person, for the 
purpose of exploitation. Exploitation shall include, at a minimum, the exploitation of the prostitution of others or other forms of sexual exploitation, forced labor or services, slavery or practices similar to slavery, servitude or the removal of organs." (UNODC, 2000).

To put it in another way, human trafficking takes place in quite a number of labor sectors, the like of manufacturing, hotel, restaurant, construction, entertainment, domestic service and sweatshop, sexual services and agricultural work. It can also take the form of international adoption, exploitation or forced surrogate pregnancies and the sales of human organs. Majority of the victims that constitute more than fifty percent are women and girls (Zimmerman, 2011). Consequently, people that are disadvantaged socially, economically and politically are most likely to be victims of human trafficking.

As a matter of fact, the international labour organisation found around twenty five million victims are yearly trafficked (ILO, 2018). That is to say, human trafficking is a serious and alarming international problem. According to Paraskevas, and Brookes (2018) article, they found the hotel industry as a key where sexual exploitation of victims is taken place. The hotels are as well utilised for labour exploitation. The author sees China, United States of America and the United Kingdom as the major culprit on this matter. Indeed, the hotel industry is a central actor where the victims are both external and internal. The authors call on the industry to critically rethink on the way and manner the hotels operate to curtail victims' exploitation sexually. Though ethical and moral policies are not and should always be adhered to. However, Smith (2018) puts human trafficking towards the radar of geography as to him there is a striking resemblance between human trafficking and the various places the exploitation takes place. Similarly, the article view population geography provides deeper knowledge on the methods of recruiting, transiting and exploiting by criminal networks.

To this end, Bowersox (2018) put the blame of migration for human trafficking largely due to natural disasters. This natural disaster such as conflict destroys not only individual security but also that of economic security of a family. Though Bowersox believes states are more equipped to tackle such disaster and save their citizens from migrating and then fallen into the trap of human traffickers. In another dimension, George and Stanley, (2018) are of the opinion that human trafficking is injustice with a longer term impact on economic wellbeing and health consequences. Indeed, it is an occupational imbalance, alienation, deprivation, and marginalization. The authors see human trafficking as a reflection of a collaborative injustice, as a result of the person's rights to political, occupational, and social violations.

\section{Methodology}

The paper is descriptive research of forced migration and human trafficking as two overlapping factors that evolve across transnational borders. Thus, a method of process tracing was used to make sure all aspects anticipated for the study were addressed. Also, it aided in identifying the causal factors in this research particular case using a grassroots approach. Thus, through the collection of multiple sources of data from peer-reviewed articles, books, official governments website and reports (Mills, Durepos \& Wiebe, 2010). Furthermore, via marking critical words, phrases or sections and although maintaining and making sure the study research questions have been initiated at the 
INTERNATIONAL JOURNAL OF ACADEMIC RESEARCH IN BUSINESS AND SOCIAL SCIENCES

Vol. 9, No. 3, March, 2019, E-ISSN: 222 2-6990 @ 2019 HRMARS

inception of the research. The central question is how religion and communities' role can assist the present state of forced migrant and human trafficking in Nigeria?

\section{Findings and Discussion}

The challenges of forced migration and human trafficking are multifaceted and also require a multidisciplinary approach. However, religion and community are two distinct perspectives, if fully utilised can minimise or lessen the migrants' sufferings'

\section{Religion}

Several government measures to tame the tide of forced migration failed to produce the desired outcome. Over 500,000 forced to migrate from Nigeria to neighboring Cameroon, Niger and Chad due to Boko Haram terrorism, the conflict between herdsmen and farmers (Lanzer, 2016; Sieff, 2017). Lack of necessary information with regards destination nations makes or forced migrants; they are ignorant of the situation in overseas countries passage, job and the present status of refugees. The religious institution does help with advocacy and awareness raising in collaboration with community leaders so as to let migrants know the difficulty of getting to a foreign country which rather ends at the mercy of human traffickers and transnational criminal. Instead of finding shelter and food but become more troubled physically and psychologically. The religious institution in Nigeria has the necessary and moral support of the general populace when it comes to speaking the truth, ills, and dangers of migration. The forced migrants will feel a sense of belonging with sister communities that are not conflict-prone to give kind help until the conflict or natural disaster is resolved. Thus, the religious body mustly sees that God-given dignity, morality, and integrity of the forced migrants must not be allowed or tolerated to be altered by human traffickers. By the same token, it is the religious institution that will call for the total elimination through advocacy and activism (Zimmerman, 2011).

\section{Community}

The vast majority of the proponents of the grassroots see nothing wrong with modernity and modern project, but they are of the view that more concern should be placed on a small scale or micro sector development. This will yield a positive result not only in skills acquisition, education of the poor. But will as well, reduce the poverty of the vulnerable and less likely to fall under the trap of the human traffickers, thereby significantly contributing to the economic growth of their community and country at large (Willis, 2011). The poor will be getting out of the poverty trap as they are able to buy goods and services as well as putting their little share of wealth into the local firms. One of the cardinal principles of grassroots approach is that it envisaged and saw the following pillars very much important, and they are: Participation: meaning an active role to move from the center, as many times the central government in Nigeria is facing with too many issues and problems to deal with, whereas the local government have little or no work. In this direction, tackling the issues of forced migration and human trafficking, there is a need for a robust decision making that both have the political and economic bearing attached to it. This is also said to bring effective and efficient service delivery. Politically, transferring actions or decision making to the community level. The populace will have their input or will be carried along on almost all activities discuss, decided and their recommendations implemented (Brinkerhoff \& Azfar, 2006). 
To this direction, human trafficking as a result of forced migration will be looked upon holistically by a community committee, identify the main problems that made trafficking to persist at this great point in time and decision made or taken for a lasting solution from the community. In addition, most importantly, people's participation in rescuing, remedying victims of forced migration and human trafficking is what participation in this perspective we are talking about. Furthermore, decisions are directed from central government to the concern communities for their active role to bring desired, or needed result not only that participation is meaningful but it should be noticed and spread amongst communities to end the forced migration that leads to human trafficking.

Empowerment on the other hand, according to Willis, one of the important concept and passionate term is empowerment in development as it allows people to do what is best for them. In the light of this, communities or societies have the intense ability to identify, tackle and implement concrete measures to solve forced migration and human trafficking from the family up to the community level by bringing all relevant stakeholders. Empowerment has helped in freeing people out of desperate and severe situations (Willis, 2011). Therefore, there is a need for programs and policies to end forced migration and human trafficking through empowerment. For example, poverty and illiteracy are often associated with an economic aspect of forced migration and human trafficking.

Certainly, individuals at the community level can decide to source or raise fund within or outside the domain to empower the poor. And with regards to illiteracy teachers amongst the community members to come up with blueprint or to develop skill acquisition centers for the vulnerable persons to participate actively and in turn solving or limiting communities' poverty level as well as providing necessary skills for the less privilege to earn a living and stand on their own in an effort to lessen forced migration and human trafficking. Furthermore, non-governmental organisations are many times seen to have a direct bearing or capable of rendering empowerment and assisting with the basics for which communities will have the know-how knowledge to start empowering their populace via collaborative work communities.

\section{Conclusion and Recommendations}

Forced migration and human trafficking have existed as a significant issue in this twenty-first century. People are forced to leave their houses due to conflict, political persecution, human-made, and natural disasters. Surely, wars and conflicts, human rights violations, authoritarian governments, tsunamis, hurricanes, climate change, and the human traffickers, have forced migrant persons out of their societies looking for protection. Likewise, communities of common concern and religious institution are essential to remedy these crucial issues in Nigeria. Empowering forced migrants and human trafficking victims with skills and education through building rapport and cooperation between vulnerable or conflict community to the nearby community will assist, work better than end at the hands of international criminals and human traffickers. The religious body best known as the public ears carries on with advocacy, enlightenment, and awareness to the populace will surely go a long way in curbing the menace. On a positive side, targeting the major causes of forced migration by partnering with non-governmental organisations will as well provide the desired outcome.

At the same time, this article contributes to knowledge through the religious institution and communities collaboration to salvage forced migrants and curtail human trafficking. Then again, this research recommends decision makers to revisit migration and human trafficking policies to ensure 
INTERNATIONAL JOURNAL OF ACADEMIC RESEARCH IN BUSINESS AND SOCIAL SCIENCES

Vol. 9, No. 3, March, 2019, E-ISSN: 222 2-6990 @ 2019 HRMARS

deeper duty to these two institutions as they are closer to the populace and problem. As well as better knowledge of the grassroots and the structures within the Nigerian communities. Lastly, the international community needs an inclusive global framework that is actively participatory to fight forced migration and human trafficking.

\section{References}

Akanle, O. (2013). Kinship Networks and International Migration in Nigeria. Cambridge: Cambridge Scholars Publishing.

Bauer, T. K., Giesecke, M., \& Janisch, L. (2017). Forced migration and mortality. Ruhr Economic. 713(2), 1-42.

Betts, A. (2009). Forced migration and global politics. West Sussex: John Wiley \& Sons.

Bowersox, Z. (2018). Natural Disasters and Human Trafficking: Do Disasters Affect State AntiTrafficking Performance? International Migration, 56(1), 196-212.

Brinkerhoff, D. W., \& Azfar, O. (2006). Decentralization and Community Empowerment: Does community empowerment deepen democracy and improve service delivery? Retrieved from https://pdfs.semanticscholar.org/9a3e/cb93bb1af2bbfde68ca2b4dee410d7e4535d.pdf

Brucker, H. Rother, N. Schupp, J. (2016). Forced migration, arrival in Germany, and first steps toward integration, DIW Economic Bulletin, 6,(48), 541-556.

Castles, S., D. \& Miller, M., J. (2013). The age of migration: International population movements in the modern world. New York: Palgrave Macmillan.

Darling, J. (2017). Forced migration and the city: Irregularity, informality, and the politics of presence. Progress in Human Geography, 41(2), 178-198.

Erdal, MB. Oeppen, C. (2018). Forced to leave? The discursive and analytical significance of describing migration as forced and voluntary. Journal of Ethnic and Migration Studies, 44,(6), 981-998.

George, E., \& Stanley, M. (2018). Exploring the occupational injustices of human trafficking. Journal of Occupational Science, 1-14.

International Labour Organisation. (2018). Forced labour, modern slavery and human trafficking. Retrieved from https://www.ilo.org/global/topics/forced-labour/lang--en/index.htm

International Organisation for Migration. (2016). Global Migration Trends Factsheet. Retrieved from https://www.iom.int/news/iom-releases-global-migration-trends-2015-factsheet

Karyotis, G. (2007). European migration policy in the aftermath of September 11: The securitymigration nexus. Innovation, 20(1), 1-17.

Lanzer, T. (2016). What's going on in Nigeria? Retrieved from

http://www.fmreview.org/solutions/lanzer.html

Mills, J. A. Durepos, G \& Wiebe, E. (2010). Encyclopedia of Case Study Research. New York: Sage publishing.

Paraskevas, A. Brookes, M. (2018). Human trafficking in hotels: an "invisible" threat for a vulnerable industry. International Journal of Contemporary Hospitality Management, 30,(3)1-36.

Reed, H. (2018). Forced Migration and Undocumented Migration and Development. Cuny Institute for Demographic Research Population Division Department of Economic and Social Affairs United Nations Secretariat. New York, 1-2 November 2018.

Sief, J. (2017). They fled Boko Haram and famine and then they were forced back. Retrieved from https://www.washingtonpost.com/.../they-fled-boko-haramthey were...back/.../e95c77. 
Smith, D, P. (2018). Population geography I: Human trafficking. Progress in Human Geography, 42(2), 297-308.

United Nations. (1951). United Nations High Commission for Refugees Convention. Retrieved from https:/unhcr.org.ua/en/who-we-help/2011-08-26-06-55-36

United Nations. (2000). Protocol to Prevent, suppress and punish trafficking in persons, especially women and children. Retrieved from https://www.unodc.org/unodc/en/treaties/CTOC/

Usman, U. M. (2014). Trafficking in women and children as vulnerable groups: Talking through theories of international relations. European Scientific Journal, 10(17), 282-292.

Usman, U. M. Ariffin, R. N. R., \& Othman, A. (2017). The Tripartite Trafficking. International Journal of Academic Research in Business and Social Sciences, 7(11), 1047-1061.

Willis, K. (2011). Theories and practices of development. London: Taylor \& Francis.

Wood, William B. (1994). Forced migration: local conflicts and international dilemmas. Annals of the Association of American geographers, 84(4), 607-634.

Yousaf, F. N. (2018). Forced migration, human trafficking, and human security. Current Sociology, 66(2), 209-225.

Zimmerman, Y. C. (2011). Christianity and human trafficking. Religion Compass, 5(10), 567-578. 